\title{
Effects of mineral and organic fertilization with the use of wet olive pomace on durum wheat performance
}

\author{
Giovanni Lacolla ${ }^{1}$ Stefania Fortunato ${ }^{2} \cdot$ Domenica Nigro $^{2} \cdot$ Maria Concetta De Pinto $^{3} \cdot$ Mario Alberto Mastro $^{1}$. \\ Davide Caranfa $^{2} \cdot$ Agata Gadaleta $^{1} \cdot$ Giovanna Cucci $^{1}$
}

Received: 14 January 2019 / Accepted: 30 July 2019 / Published online: 12 August 2019

(c) The Author(s) 2019

\begin{abstract}
Purpose Despite durum wheat accounts for only $5 \%$ of the global wheat production, it represents an economically important species, as a basic food and primary source of daily caloric intake in the Mediterranean basin area. By-products of agricultural processing, such as pomace, can be used to increase soil fertility, as they are indeed a source of important nutrients useful for crop growth.

Methods The present research was carried out on durum wheat, as part of a long-term experiment. The study aimed at assessing the effects of mineral and organic fertilization with the use of wet olive pomace on a 3-year trial with crops grown in succession (fava beans-wheat-spelt). A split-plot experimental design with three replicates was used. The cultivars (Aureo and Vespucci) were assigned to the main plots and the seven fertilization treatments to the sub-plots.

Results Our result showed that supplying wet olive pomace as soil improver was not sufficient to significantly improve soil fertility compared to the unfertilized control. However, when $60 \mathrm{~kg} \mathrm{ha}^{-1}$ of nitrogen was supplied in coverage before tillering, in addition to $70 \mathrm{Mg} \mathrm{ha}^{-1}$ of wet olive pomace yield an increase of $66 \%$ in Aureo cv and of $222 \%$ in Vespucci cv, in comparison to the unfertilized crop.

Conclusion The best management of fertilizers, associated with the use of more nitrogen-use-efficient genotypes, is essential for the development of a sustainable agriculture.
\end{abstract}

Keywords Wheat cultivars $\cdot$ Fertilization $\cdot$ Wet olive pomace Top-Phos $\cdot$ Chlorophylls

\section{Introduction}

Nitrogen is one of the most important limiting factors for plant growth and development, as its soil availability influences both crop production and quality (Marschner 1995; Epstein and Bloom 2005). The use of mineral fertilizers has

Giovanna Cucci

giovanna.cucci@uniba.it

Giovanni Lacolla

giovanni.lacolla@uniba.it

Stefania Fortunato

stefania.fortunato@uniba.it

Domenica Nigro

domenica.nigro@uniba.it

Maria Concetta De Pinto

mariaconcetta.depinto@uniba.it

Mario Alberto Mastro

mario.alberto.mastro@uniba.it become a regular strategy all over the world to remedy the nitrogen deficiency and increase crop yields, with benefits for intensive farming (Laidig et al. 2017). However, these agronomic practices have contributed to a number of environmental problems, such as biodiversity reduction, air pollution caused by gas emissions, acid rain, and groundwater

Davide Caranfa

davide.caranfa@gmail.com

Agata Gadaleta

agata.gadaleta@uniba.it

1 Department of Agricultural and Environmental Science, University of Bari Aldo Moro, Bari, Italy

2 Department of Soil, Plant and Food Sciences, University of Bari Aldo Moro, Bari, Italy

3 Department of Biology, University of Bari Aldo Moro Bari, Bari, Italy 
pollution (Andrews et al. 2011; Butler et al. 2012). For these reasons, it is important to adopt alternative strategies that can limit and/or reverse this trend, so that soil damaging can be stopped.

To promote sustainable agriculture, organic waste can be considered as an important resource. By-products of agricultural processing, manure, and other organic residues can indeed be used to increase soil fertility, as they are a source of important nutrients useful for crop growth, as well as for an overall improvement in soil quality (Davies and Lennartsson 2005; Erana et al. 2019).

In many Mediterranean regions, olive oil production represents one of the most important resources in the agroindustrial sector.

The processes necessary for olive oil production lead to the formation of a semi-solid waste residue, the olive pomace. Wet olive pomace is thus a secondary product of the olive mills during olive oil processing, very abundant in the olive oil producing countries along the Mediterranean area. Due to progressive changes in olive-mill machineries to increase oil yields, nowadays pomace has on average a greater moisture (55-65\%) and a lower oil content than in the past; in addition, a lower amount of vegetable water is produced. For this reason, quite often the pomace extracting industries do not consider economically convenient to buy it and the product has difficult commercial collocation, representing a waste which has to be properly discarded.

Wet olive pomace contains, however, large amounts of organic matter and nutrients (Alfano et al. 2008) and could, therefore, represent a valid soil amendment being conveniently reused in agriculture.

Studies carried out on this topic showed that the use of wet olive pomace and vegetable water as fertilizing matrices, on both herbaceous and tree crops, can give positive results on yield (Briccoli et al. 2002) and, similarly, can contribute to an increase in the content of soil organic matter and provide macro- and micro-elements (in particular nitrogen, potassium and zinc, magnesium, and copper), important for plant nutrition (Cucci et al. 2008, 2013).

These results can be observed mostly in the long term in relation to the quantities applied (Saviozzi et al. 1991), after the wet olive pomace and vegetable water have undergone a series of biochemical transformations, and can be then integrated into the soil system; on the other hand, in the short term, there may be alterations in the acidity of the soils and in the mobility of some ions, as well as the occurrence of temporary phytotoxic effects (Montemurro et al. 2004).

The aim of this work was to evaluate the effects of two different types of fertilization, inorganic and organic, on wheat yield and yield components, and on the final grain protein content (GPC) in two durum wheat varieties, Aureo and Vespucci. These two varieties have been chosen within a national collection of tetraploid wheats, because they have good productivity and GPC parameters, as shown by the evaluations for 2 consecutive years in different environments in Italy carried out by CREA (Council for Agricultural Research and Economics) (Quaranta et al. 2016).

\section{Materials and methods}

The research was carried out on durum wheat, as part of a long-term trial. The aim of the study was to assess the effects of mineral and organic fertilization with the use of wet olive pomace (WP) on a 3-year trial with crops grown in succession (fava beans-wheat-spelt). This type of crop rotation (legume-cereal-cereal) is widespread in Southern Italy. The amounts of WP supplied are indicated by the current legislation in Italy, which allows for the agronomic use of this by-product in three possible alternatives: distribution of $1 / 3$ of the maximum expected each year of cultivation $\left(70 \mathrm{Mg} \mathrm{ha}^{-1}\right)$; distribution of $2 / 3$ of the maximum $\left(140 \mathrm{Mg} \mathrm{ha}^{-1}\right)$ in the first year and $1 / 3$ in the second year; only distribution of $210 \mathrm{Mg} \mathrm{ha}^{-1}$ of waste as such once every 3 years.

The experimentation was carried out in the 2016-2017 agricultural season, at DiSAAT (Department of Agricultural and Environmental Science, University of Bari Aldo Moro, Italy) on two durum wheat cvs (Triticum durum Desf.). Aureo and Vespucci cvs were grown in succession to fava bean, in a total of 42 containers of $0.72 \mathrm{~m}$ diameter and $0.60 \mathrm{~m}$ height, filled with $293 \mathrm{~kg}$ of sandy-loam soil having good fertility, whose main physico-chemical characteristics are described in Cucci et al. (2019).

A split-plot experimental design with three replicates was used. The cultivars (Aureo and Vespucci) were assigned to the main plots and the seven fertilization treatments to the sub-plots (a non-fertilized control, three conventional mineral fertilization treatments and three organic fertilization treatments with wet olive pomace, WP).

In the conventional mineral fertilization, the three treatments consisted of nitrogen, phosphorus, and potassium supplied as follows: $\mathrm{N} 120 \mathrm{~kg} \mathrm{ha}^{-1}, \mathrm{P}_{2} \mathrm{O}_{5} 100 \mathrm{~kg} \mathrm{ha}^{-1}$, and $\mathrm{K}_{2} \mathrm{O} 100 \mathrm{~kg} \mathrm{ha}^{-1}$, as usual for durum wheat cropping in Southern Italy. Although the amount of phosphorus supplied was the same for the three treatments, the source of phosphorus used was different: in the first one, only single mineral superphosphate was supplied (hereafter named sample C1); in the second one, phosphorus was supplied with Fosfactyl, Top-Phos MPPA D-Coder 3-22, respectively, of N and $\mathrm{P}_{2} \mathrm{O}_{5}$ with phosphorus protected by activated polyphenolic molecules (sample $\mathrm{C} 2$ ); in the third treatment, phosphorus was instead supplied with half of the phosphorous in the form of simple mineral superphosphate and the remainder in the form of Top-Phos (sample C3). The nitrogen was supplied in the form of ammonium nitrate (30\% was applied at 
sowing and the remaining dose at coverage before the stage of stem elongation). Potassium was applied in the form of potassium sulfate.

In the treatments with organic fertilization, hereafter named P1, P2, and P3, wet olive pomace doses were supplied according to the 3-year trial and the current Italian legislation previously reported $\left(70 \mathrm{Mg} \mathrm{ha}^{-1}\right.$ in $\mathrm{P} 1$ and $\mathrm{P} 2$, and no doses in P3) (Italian law No. 574 of 11th November 1996). Only the treatments $P 1$, at the beginning of the stem elongation phase, were also fertilized with $60 \mathrm{~kg} \mathrm{ha}^{-1}$ nitrogen in the form of ammonium nitrate. The treatments details are reported in Table 1 . The main characteristics of the wet olive pomace are shown in Table 2.

The wet pomace was distributed and buried in the $0-20 \mathrm{~cm}$ soil layer, a month before wheat sowing. The sowing was carried out on November 25th 2016, by planting 350 seeds $\mathrm{m}^{-2}$, distributed in three rows in each pot. From the seedling emergence to the end of the crop cycle, irrigation was made whenever there was a $50 \%$ of water loss due to evapotranspiration, and the volume was calculated to restore field capacity in each pot.

To evaluate the influence of WP on photosynthetic pigments content, the crop fertilized with only wet olive pomace without mineral nitrogen fertilization (treatment P2) was selected and compared with conventional fertilization (C1) and the non-fertilized control (T). To this aim, at tillering stage, $0.3 \mathrm{~g}$ of fresh leaves were sampled. The collected samples were immediately frozen in liquid nitrogen and stored at $-80^{\circ} \mathrm{C}$.

For the determination of photosynthetic pigments, frozen leaves were grounded in liquid nitrogen in a mortar with $1: 30(\mathrm{w} / \mathrm{v}) 80 \%$ acetone. Crude extracts were centrifuged at $10,000 \times g$ for $20 \mathrm{~min}$ at $4^{\circ} \mathrm{C}$ (Eppendorf 5417R).
Table 2 Physico-chemical properties of wet olive pomace used in the fertilization trials

\begin{tabular}{lcl}
\hline Parameter & Value & References \\
\hline $\mathrm{pH}$ & 5.36 & ANPA (2001) \\
Moisture $\left(\mathrm{g} \mathrm{kg}^{-1} \mathrm{dw}\right)$ & 549.0 & ANPA (2001) \\
Organic C $\left(\mathrm{g} \mathrm{kg}^{-1} \mathrm{dw}\right)$ & 525.7 & ANPA (2001) \\
Phenols $\left(\mathrm{mg} \mathrm{g}^{-1} \mathrm{dw}\right)$ & 12.47 & Singleton et al. (1999) \\
Fats $\left(\mathrm{g} \mathrm{kg}^{-1} \mathrm{dw}\right)$ & 100.2 & AOAC (1990) \\
Total N $\left(\mathrm{g} \mathrm{kg}^{-1} \mathrm{dw}\right)$ & 10.8 & ANPA (2001) \\
Total P $\left(\mathrm{g} \mathrm{kg}^{-1} \mathrm{dw}\right)$ & 2.1 & ANPA (2001) \\
Total K $\left(\mathrm{g} \mathrm{kg}^{-1} \mathrm{dw}\right)$ & 13.6 & ANPA (2001) \\
$\mathrm{Zn}\left(\mathrm{mg} \mathrm{kg}^{-1} \mathrm{dw}\right)$ & 19.00 & ANPA (2001) \\
$\mathrm{Mn}\left(\mathrm{mg} \mathrm{kg}^{-1} \mathrm{dw}\right)$ & 11.00 & ANPA (2001) \\
$\mathrm{Cu}\left(\mathrm{mg} \mathrm{kg}^{-1} \mathrm{dw}\right)$ & 16.90 & ANPA (2001) \\
$\mathrm{Cr}, \mathrm{Ni}, \mathrm{Co}, \mathrm{Pb}, \mathrm{Cd}\left(\mathrm{mg} \mathrm{kg}^{-1} \mathrm{dw}\right)$ & $<1$ & ANPA (2001) \\
\hline
\end{tabular}

$d w$ dry weight

The supernatants were used to determine the absorbance at $663.2,648.8$, and $470 \mathrm{~nm}$, by visible spectrophotometry. The content of chlorophylls was calculated as described by the following Zhang and Kirkham (1996):

Chlorophyll $\mathrm{a}=(12.25 \cdot$ Ass $663.2 \mathrm{~nm})-(2.79 \cdot$ Ass $648.8 \mathrm{~nm})$

Chlorophyll $\mathrm{b}=(21.50 \cdot$ Ass. $648.8 \mathrm{~nm})-(5.10 \cdot$ Ass. $663.2 \mathrm{~nm})$

Carotenoids $=((100 \cdot$ Ass. $470.0 \mathrm{~nm})-(1.82 \cdot$ chlorophyll a $)$

$$
-(85.2 \cdot \text { chlorophyll b) }) / 198 \text {. }
$$

The values were then related to the initial weight, to express the content of photosynthetic pigments in fresh weight $\mathrm{mg} \mathrm{g}^{-1}$.
Table 1 Fertilization conditions applied to Wheat

\begin{tabular}{lllll}
\hline Fertilization type & $\begin{array}{l}\text { Wet pomace } \\
\left(\mathrm{Mg} \mathrm{ha}^{-1}\right)\end{array}$ & $\begin{array}{l}\mathrm{N} \\
\left(\mathrm{kg} \mathrm{ha}^{-1}\right)\end{array}$ & $\begin{array}{l}\mathrm{P}_{2} \mathrm{O}_{5} \\
\left(\mathrm{~kg} \mathrm{ha}^{-1}\right)\end{array}$ & $\begin{array}{l}\mathrm{K}_{2} \mathrm{O} \\
\left(\mathrm{kg} \mathrm{ha}^{-1}\right)\end{array}$ \\
\hline $\begin{array}{l}\text { Unfertilized (T) } \\
\text { Mineral }\end{array}$ & 0 & 0 & 0 & 0 \\
C1 & 0 & 120 & 100 & 100 \\
C2 & 0 & Ammonium nitrate & $\begin{array}{l}\text { Simple super- } \\
\text { phosphate }\end{array}$ & Potassium sulfate \\
C3 & 0 & Ammonium nitrate & $\begin{array}{l}\text { Top-Phos } \\
\text { Top-Phos + sim- }\end{array}$ & $\begin{array}{l}\text { Potassium sulfate } \\
\text { Ple superphos- }\end{array}$ \\
& & Ammonium nitrate & \\
Organic & & & phate & \\
P1 & 70 & 60 & 0 & 0 \\
P2 & 0 & 0 & 0 & 0 \\
P3 & 0 & 0 & 0 & 0 \\
\hline
\end{tabular}

$C$ conventional fertilization, $P$ fertilization based on the secondary product (wet pomace) of oil productive process

${ }^{\dagger}$ In the previous cropping season, there was supplied $210 \mathrm{Mg} \mathrm{ha}^{-1}$ wet olive pomace 
Moreover, the chlorophyll index was measured before and after flowering using the Chlorophyll Meter, SPAD-502, Minolta, to characterize the crop nitrogen status.

Samples were harvested at maturity on June 15th 2017, and the main morphological, productive, and technological parameters were evaluated: plant height, culms, ears, shoot dry biomass, seed yield, 1000 seed weight, hectoliter weight, and grain protein content. All production parameters were determined in each pot and referred to the square meter or hectare surface.

Grain protein content (GPC) was determined (according to Lin et al. 2014) on a representative sample of $3 \mathrm{~g}$ of whole wheat flour by near-infrared reflectance spectroscopy (Zeutec Spectra Alyzer Premium, Zeutec Büchi, Rendsburg, Germany). All the detected parameters were analyzed using the ANOVA statistical procedure and the Student-Newman-Keuls (SNK) test was used to highlight differences among the means.

\section{Results and discussion}

In this study, we investigated the effect of using both wet olive pomace (WP) and mineral fertilization on two durum wheat cultivars as a part of a 3-year/crop rotation with fava beans and spelt, and several considerations could be drawn. The high humidity and oil content of WP caused difficulties during both the spreading operations and the subsequent homogenization with the soil. This could be the cause of phytotoxic phenomena, as observed in other studies (Paris 1998), where negative effects on the seedlings since emergence were observed in the samples with higher amount of amending material.

The young seedlings directly in contact with the WP particles during the very early stages of development (germination-emergence) showed a reduced and slower growth than those in the pots supplied with lower doses of WP and in control samples. Even during the subsequent phenological stages, evident differences in plant growth were observed in relation to increasing doses of WP. According to previous findings on this species grown under stress condition (Paris 1998), plants treated with WP show longer vegetative phases and shorter reproductive ones.

Since a part of the organic nitrogen can be stored in the photosynthetic pigments in leaves, the levels of chlorophyll $\mathrm{a}$, chlorophyll $\mathrm{b}$, and carotenoids were analyzed during tillering stage in plants supplied with the two different types of fertilization. Mineral fertilization led to an increase in the three types of photosynthetic pigments for both varieties; on the contrary, there was no significant difference of chlorophyll and carotenoids contents measured in the leaves of plants treated with pomace and in control samples (Table 3 ).
Table 3 Content of chlorophyll a, chlorophyll b, and carotenoids in leaves of two durum wheat varieties supplied with conventional mineral fertilization and organic fertilization with wet olive pomace

\begin{tabular}{|c|c|c|c|}
\hline \multirow[t]{2}{*}{$\begin{array}{l}\text { Fertilization } \\
\text { type }\end{array}$} & $\begin{array}{l}\text { Chlorophyll } \\
\text { a }\end{array}$ & $\begin{array}{l}\text { Chlorophyll } \\
\text { b }\end{array}$ & Carotenoids \\
\hline & $\mu \mathrm{g} g / \mathrm{FW}$ & $\mu \mathrm{g} g / \mathrm{FW}$ & $\mu \mathrm{g} g / \mathrm{FW}$ \\
\hline \multicolumn{4}{|l|}{ AUREO } \\
\hline $\mathrm{T}$ & $535.27 \mathrm{~B}$ & $225.75 B$ & 144.92B \\
\hline $\mathrm{C} 1$ & $1432.23 \mathrm{~A}$ & $639.66 \mathrm{~A}$ & $236.63 \mathrm{~A}$ \\
\hline $\mathrm{P} 2$ & $559.68 \mathrm{~B}$ & 216.89B & 149.86B \\
\hline \multicolumn{4}{|l|}{ VESPUCCI } \\
\hline $\mathrm{T}$ & 578.93B & $250.39 \mathrm{~B}$ & 173.54B \\
\hline $\mathrm{C} 1$ & $1151.25 \mathrm{~A}$ & $541.11 \mathrm{~A}$ & $290.51 \mathrm{~A}$ \\
\hline $\mathrm{P} 2$ & $647.53 \mathrm{~B}$ & 265.92B & 161.83B \\
\hline
\end{tabular}

$T$ unfertilized soil, $C 1$ mineral fertilization: $\mathrm{N} 120, \mathrm{P}_{2} \mathrm{O}_{5} 100$ and $100 \mathrm{~K}_{2} \mathrm{O} \mathrm{Kg} \mathrm{ha}{ }^{-1}$. P2 organic fertilization with $70 \mathrm{Mg} \mathrm{ha}^{-1}$ wet olive pomace, without mineral fertilization. Different letters in column indicate significant differences according to the SNK test at $P \leq 0.01$

To have an indirect measure of the plant nutritional status during growth, the total chlorophyll content in leaves was assessed by SPAD measurements (chlorophyll index) at booting and flowering stages; the index confirmed the trend of photosynthetic pigments observed in the different treatments at tillering stage, with the mineral fertilized plants showing the highest values.

The two cultivars showed similar SPAD values at booting, whereas at flowering, significantly greater values were observed for Vespucci (Table 4; Figs. 1 and 2). No significant interaction was observed between cultivar and fertilization treatment compared (Table 4) and inorganic fertilization resulted in a significant increase in SPAD values in both varieties, both at booting and flowering phases. Organic fertilization induced no significant variation of SPAD values in both cultivars in the two different stages compared to the control treatment, apart a greater value at both phenological stages for treatment $\mathrm{P} 1$, which received $60 \mathrm{~kg} \mathrm{ha}^{-1}$ of $\mathrm{N}$ in addition to the organic amendment $\left(70 \mathrm{Mg} \mathrm{ha}^{-1}\right.$ of WP).

Significant interactions between cultivars and fertilization were recorded for morphological parameters (Tables 4 and 5). In Aureo, the lowest plant height was recorded in the non-fertilized test, and no significant difference was found in the two types of fertilization (organic and mineral). In Vespucci, the highest plant height was found only in the three treatments with mineral fertilization, but no difference between control and organic fertilization was observed (Tables 4 and 5).

In both cvs, the highest number of tillers was observed when mineral fertilization was supplied. This number decreased with the other treatments, and the values were not significantly different from the control samples (Tables 4 and 5). Spike number $\mathrm{m}^{-2}$ showed decreasing values from 
Table 4 The effect of cultivars and fertilization on morphological, commercial, and physiological parameters of durum wheat

\begin{tabular}{|c|c|c|c|c|c|c|c|c|c|}
\hline $\begin{array}{l}\text { Sources of } \\
\text { variation }\end{array}$ & $\begin{array}{l}\text { Plant height } \\
(\mathrm{cm})\end{array}$ & $\begin{array}{l}\text { Total culms } \\
\left(\mathrm{nm}^{-2}\right)\end{array}$ & $\begin{array}{l}\text { Total ear } \\
\left(\mathrm{nm}^{-2}\right)\end{array}$ & $\begin{array}{l}\text { Shoot dry } \\
\text { biomass } \\
\left(\mathrm{Mg} \mathrm{ha}^{-1}\right)\end{array}$ & $\begin{array}{l}\text { Kernel yield } \\
\left(\mathrm{Mg} \mathrm{ha}^{-1}\right)\end{array}$ & $\begin{array}{l}1000 \text { seed } \\
\text { weight } \\
\text { g }\end{array}$ & $\begin{array}{l}\text { Hectoliter } \\
\text { ker. weight } \\
\mathrm{Kg} \mathrm{HL}^{-1}\end{array}$ & $\begin{array}{l}\text { SPAD at } \\
\text { booting } \\
\text { (index) }\end{array}$ & $\begin{array}{l}\text { SPAD at } \\
\text { flowering } \\
\text { (index) }\end{array}$ \\
\hline \multicolumn{10}{|l|}{ Cultivars } \\
\hline Aureo & $74.5 \mathrm{~A}$ & 396.7A & $369.6 \mathrm{~A}$ & $8.82 \mathrm{~B}$ & $3.75 \mathrm{~B}$ & 44.7B & $80.1 \mathrm{~B}$ & $34.4 \mathrm{~A}$ & $36.4 \mathrm{~B}$ \\
\hline Vespucci & $78.1 \mathrm{~A}$ & $402.4 \mathrm{~A}$ & $377.4 \mathrm{~A}$ & $10.84 \mathrm{~A}$ & 4.77A & 48.9A & $81.9 \mathrm{~A}$ & $35.8 \mathrm{~A}$ & $40.1 \mathrm{~A}$ \\
\hline \multicolumn{10}{|l|}{ Fertilization } \\
\hline $\mathrm{T}$ & $66.3 \mathrm{~B}$ & 317.4B & $290.5 \mathrm{C}$ & $3.7 \mathrm{C}$ & $1.5 \mathrm{C}$ & $44.4 \mathrm{C}$ & $78.8 \mathrm{C}$ & $19.5 \mathrm{C}$ & $21.2 \mathrm{D}$ \\
\hline $\mathrm{C} 1$ & $85.4 \mathrm{~A}$ & 491.7A & 459.9A & $15.8 \mathrm{~A}$ & $7.1 \mathrm{~A}$ & $48.5 \mathrm{~A}$ & $82.3 \mathrm{~A}$ & $46.4 \mathrm{~A}$ & $49.0 \mathrm{~A}$ \\
\hline $\mathrm{C} 2$ & $87.5 \mathrm{~A}$ & $488.3 \mathrm{~A}$ & $455.3 \mathrm{~A}$ & $16.4 \mathrm{~A}$ & $6.6 \mathrm{~A}$ & $49.2 \mathrm{~A}$ & $83.0 \mathrm{~A}$ & $51.0 \mathrm{~A}$ & $52.25 \mathrm{~A}$ \\
\hline $\mathrm{C} 3$ & 81.7A & $483.0 \mathrm{~A}$ & $451.2 \mathrm{~A}$ & $15.1 \mathrm{~A}$ & $6.7 \mathrm{~A}$ & $48.4 \mathrm{~A}$ & $82.5 \mathrm{~A}$ & $46.5 \mathrm{~A}$ & $50.6 \mathrm{~A}$ \\
\hline $\mathrm{P} 1$ & $73.8 \mathrm{~B}$ & $354.5 \mathrm{~B}$ & $329.8 \mathrm{~B}$ & $6.4 \mathrm{~B}$ & $3.6 \mathrm{~B}$ & $47.0 \mathrm{~B}$ & $81.2 \mathrm{~B}$ & $32.4 \mathrm{~B}$ & $39.8 \mathrm{~B}$ \\
\hline $\mathrm{P} 2$ & $70.4 \mathrm{~B}$ & 335.9B & 313.3B & $5.3 \mathrm{BC}$ & $2.4 \mathrm{C}$ & $45.7 \mathrm{C}$ & $80.2 \mathrm{~B}$ & $25.0 \mathrm{C}$ & $28.1 \mathrm{C}$ \\
\hline P3 & 70.7B & 323.9B & 308.2B & $4.7 \mathrm{C}$ & $2.1 \mathrm{C}$ & $44.9 \mathrm{C}$ & $80.0 \mathrm{~B}$ & $25.6 \mathrm{C}$ & $28.55 \mathrm{C}$ \\
\hline \multicolumn{10}{|l|}{ Significance } \\
\hline Cultivars & $*$ & ns & ns & $* *$ & $* *$ & $* *$ & $* *$ & $\mathrm{~ns}$ & $* *$ \\
\hline Fertilization & $* *$ & $* *$ & $* *$ & $* *$ & $* *$ & $* *$ & $* *$ & $* *$ & $* *$ \\
\hline Interactions ${ }^{\dagger}$ & ns & ns & $*$ & $*$ & $*$ & $* *$ & $*$ & ns & ns \\
\hline
\end{tabular}

$T$ unfertilized soil, $C 1$ mineral fertilization mineral with superphosphate 19-21 of $\mathrm{P}_{2} \mathrm{O}_{5} . C 2$ mineral fertilization with Top-Phos, Fosfactyl of $\mathrm{P}_{2} \mathrm{O}_{5}, C 3$ mineral fertilization with $1 / 2$ Top-Phos, Fosfactyl $+1 / 2$ mineral superphosphate. $\mathrm{P} 1=70 \mathrm{Mg} \mathrm{ha}{ }^{-1}$ wet olive pomace $+60 \mathrm{~kg} / \mathrm{ha} \mathrm{N} \mathrm{during}$ stem elongation stage. $\mathrm{P} 2$ and $\mathrm{P} 3=70$ and $0 \mathrm{Mg} \mathrm{ha}^{-1}$ wet olive pomace, respectively, without mineral fertilization

$n s$ non-significant

*, **Significant at $P \leq 0.05$ and 0.01 , respectively. For each effect considered, the values followed by the same letter are not significantly different, according to the SNK test at $P \leq 0.01$

${ }^{\dagger}$ All interactions among each treatment were tested

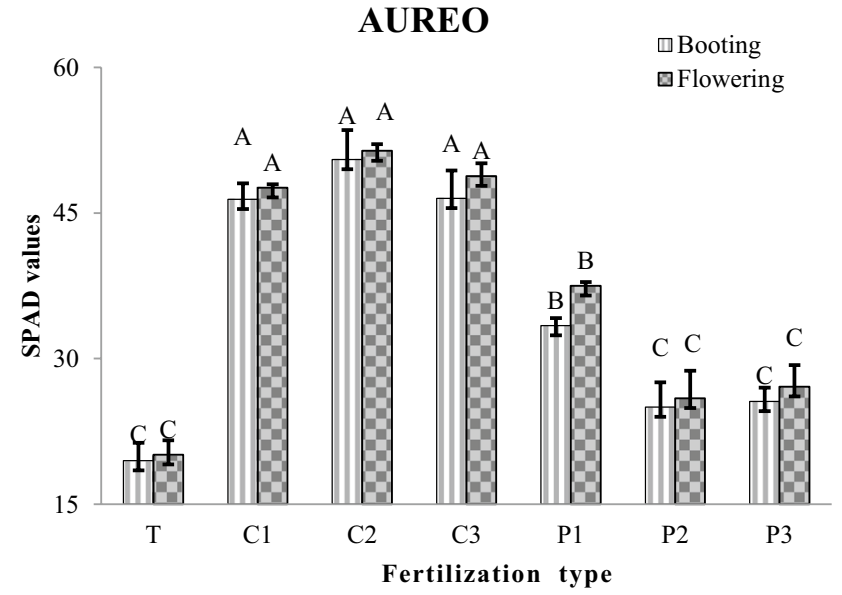

Fig. 1 Effects of mineral and organic fertilization on chlorophyll index (SPAD values) of two durum wheat cultivars. $T$ unfertilized soil. $\mathrm{C} 1=$ mineral fertilization mineral with superphosphate $19-21$ of $\mathrm{P}_{2} \mathrm{O}_{5}$. C2 $=$ mineral fertilization with Top-Phos, Fosfactyl of $\mathrm{P}_{2} \mathrm{O}_{5}$. $\mathrm{C} 3=$ mineral fertilization with $1 / 2$ Top-Phos, Fosfactyl $+1 / 2$ mineral superphosphate. $\mathrm{P} 1=70 \mathrm{Mg} \mathrm{ha}^{-1}$ wet olive pomace $+60 \mathrm{~kg} / \mathrm{ha} \mathrm{N}$ dur-

mineral fertilization, to the one integrated with $60 \mathrm{~kg} \mathrm{ha}^{-1}$ of ammonium nitrate, and the lowest values were registered for organic supplement and control samples.

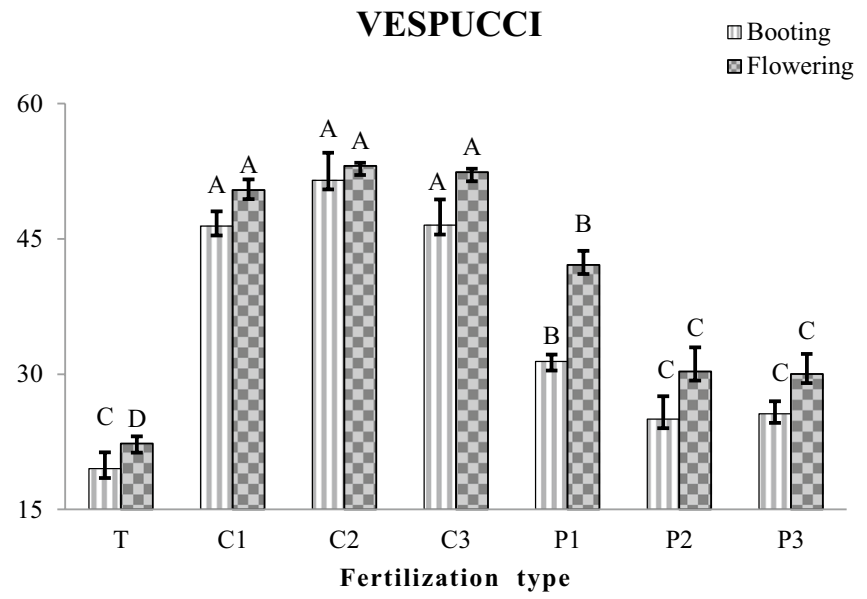

ing stem elongation stage. $\mathrm{P} 2$ and $\mathrm{P} 3=70$ and $0 \mathrm{Mg} \mathrm{ha}^{-1}$ wet olive pomace, respectively, without mineral fertilization. Vertical bars represent the standard errors of means. For each phase, different letters in column indicate significant differences according to the SNK test at $P \leq 0.01$

Consequently, in both cultivars, the highest production of shoot dry biomass was observed with mineral fertilization. In Aureo, no significant difference was found among 


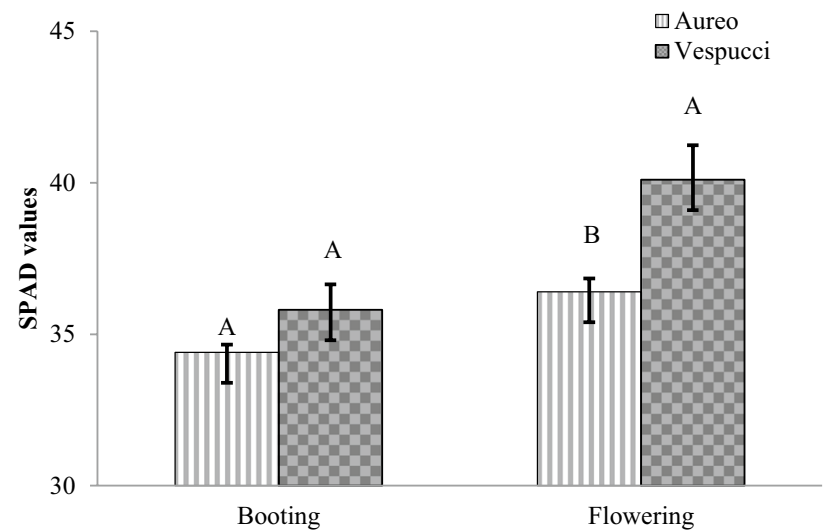

Fig. 2 Variation of chlorophyll index (SPAD values) at booting and flowering phases in two durum wheat cultivars. Vertical bars represent the standard errors of means. Different letters in column indicate significant differences according to the SNK test at $P \leq 0.01$

the different types of organic fertilization (P1, P2, and P3) which showed significantly higher values than the control (Table 5). In Vespucci, treatment P1 (organic fertilization integrated with $\mathrm{N}$ ) showed significantly greater production of dry biomass in comparison to the unfertilized control, while the treatments receiving only the organic fertilization (P2 and P3) showed intermediate and not significantly different behavior (Table 5).
Thousand kernel weight was higher in Vespucci (45.7 g) than Aureo (43 g), yet under control conditions. The inorganic fertilization promoted a significant increase of this parameter in both varieties. Despite values that were slightly higher in treated Vespucci samples, they were not significantly different among organic treatments and control. Aureo, however, showed no significant differences in thousand kernel weight among the different organic supplemented samples, and values (Tables 4 and 5).

The hectoliter weight did not show significant differences in the two varieties under control conditions $\left(78.8 \mathrm{~kg} \mathrm{HL}^{-1}\right)$, whilst significantly increased only in Vespucci variety subjected to inorganic fertilization $\left(83.5 \mathrm{~kg} \mathrm{HL}^{-1}\right)$. Also the grain harvested per hectare was not significantly different in the two varieties under control conditions, but the mineral fertilization promoted an increase in both varieties, though higher in Vespucci. These data suggested that, in productive terms, Vespucci responded better to fertilization treatments compared to Aureo.

The reduced availability of $\mathrm{N}$ in the soil is often considered to be the main factor responsible for the low crop productivity. Unfortunately, nitrogen supplied with organic fertilizer takes longer time to become available for plants (Krapp 2015), while N supplied with mineral fertilizers is readily available. Therefore, with the supplying of $60 \mathrm{~kg} \mathrm{ha}^{-1}$ of nitrogen in coverage before tillering in addition to $70 \mathrm{Mg} \mathrm{ha}^{-1}$ of wet olive pomace (treatment P1), yield

Table 5 Yield-related traits observed in two durum wheat cultivars grown under different fertilization regimes

\begin{tabular}{|c|c|c|c|c|c|c|}
\hline $\begin{array}{l}\text { Fertilization } \\
\text { type }\end{array}$ & $\begin{array}{l}\text { Plant height } \\
(\mathrm{cm})\end{array}$ & $\begin{array}{l}\text { Total culms } \\
\left(\mathrm{n} \mathrm{m}^{-2}\right) \\
\end{array}$ & $\begin{array}{l}\text { Total } \\
\text { ear } \\
\left(\mathrm{n} \mathrm{m}^{-2}\right)\end{array}$ & $\begin{array}{l}\text { Shoot dry biomass } \\
\left(\mathrm{Mg} \mathrm{ha}^{-1}\right)\end{array}$ & 1000 seed weight & $\begin{array}{l}\text { Hectoliter kernel weight } \\
\mathrm{Kg} \mathrm{HL}^{-1}\end{array}$ \\
\hline \multicolumn{7}{|l|}{ Aureo } \\
\hline $\mathrm{T}$ & $68.3 \pm 1.6 \mathrm{~B}$ & $318.0 \pm 2.9 \mathrm{~B}$ & $292.4 \pm 4.2 \mathrm{C}$ & $4.09 \pm 0.7 \mathrm{C}$ & $43.0 \pm 0.6 \mathrm{C}$ & $78.3 \pm 0.4 \mathrm{C}$ \\
\hline $\mathrm{C} 1$ & $80.7 \pm 1.15 \mathrm{~A}$ & $500.8 \pm 8.5 \mathrm{~A}$ & $465.2 \pm 4.7 \mathrm{~A}$ & $14.73 \pm 1.0 \mathrm{~A}$ & $45.7 \pm 0.9 \mathrm{~A}$ & $81.3 \pm 0.3 \mathrm{AB}$ \\
\hline $\mathrm{C} 2$ & $86.7 \pm 2.8 \mathrm{~A}$ & $477.3 \pm 5.4 \mathrm{~A}$ & $442.4 \pm 3.9 \mathrm{~A}$ & $15.42 \pm 0.9 \mathrm{~A}$ & $46.7 \pm 0.4 \mathrm{~A}$ & $82.0 \pm 0.6 \mathrm{~A}$ \\
\hline $\mathrm{C} 3$ & $76.7 \pm 1.4 \mathrm{~A}$ & $491.7 \pm 6.2 \mathrm{~A}$ & $459.1 \pm 1.3 \mathrm{~A}$ & $13.41 \pm 0.7 \mathrm{~A}$ & $45.7 \pm 0.5 \mathrm{~A}$ & $81.7 \pm 0.5 \mathrm{AB}$ \\
\hline P1 & $70.0 \pm 1.9 \mathrm{~B}$ & $354.6 \pm 3.2 \mathrm{~B}$ & $330.8 \pm 8.2 \mathrm{~B}$ & $5.10 \pm 0.6 \mathrm{~B}$ & $44.5 \pm 06 \mathrm{~B}$ & $79.7 \pm 0.4 \mathrm{BC}$ \\
\hline $\mathrm{P} 2$ & $70.7 \pm 1.6 \mathrm{~B}$ & $336.2 \pm 4.1 \mathrm{~B}$ & $318.2 \pm 7.5 \mathrm{BC}$ & $4.52 \pm 0.9 \mathrm{~B}$ & $44.3 \pm 0.3 \mathrm{~B}$ & $79.3 \pm 0.3 \mathrm{BC}$ \\
\hline P3 & $71.7 \pm 0.5 \mathrm{~B}$ & $322.0 \pm 5.6 \mathrm{~B}$ & $297.7 \pm 5.2 \mathrm{BC}$ & $4.49 \pm 0.8 \mathrm{~B}$ & $43.7 \pm 0.3 \mathrm{BC}$ & $79.7 \pm 0.3 \mathrm{BC}$ \\
\hline \multicolumn{7}{|l|}{ Vespucci } \\
\hline $\mathrm{T}$ & $64.3 \pm 3.3 \mathrm{~B}$ & $316.7 \pm 2.5 \mathrm{~B}$ & $288.6 \pm 3.7 \mathrm{C}$ & $3.37 \pm 0.2 \mathrm{C}$ & $45.7 \pm 0.4 \mathrm{~B}$ & $79.3 \pm 0.3 \mathrm{C}$ \\
\hline $\mathrm{C} 1$ & $90.0 \pm 5.0 \mathrm{~A}$ & $482.6 \pm 7.6 \mathrm{~A}$ & $454.5 \pm 5.4 \mathrm{~A}$ & $16.78 \pm 0.5 \mathrm{~A}$ & $51.3 \pm 0.3 \mathrm{~A}$ & $83.3 \pm 0.5 \mathrm{~A}$ \\
\hline $\mathrm{C} 2$ & $88.3 \pm 4.8 \mathrm{~A}$ & $499.2 \pm 9.7 \mathrm{~A}$ & $468.2 \pm 6.2 \mathrm{~A}$ & $17.35 \pm 0.6 \mathrm{~A}$ & $51.7 \pm 0.2 \mathrm{~A}$ & $84.0 \pm 0.5 \mathrm{~A}$ \\
\hline $\mathrm{C} 3$ & $86.7 \pm 2.8 \mathrm{~A}$ & $474.2 \pm 8.1 \mathrm{~A}$ & $443.2 \pm 4.8 \mathrm{~A}$ & $16.70 \pm 0.7 \mathrm{~A}$ & $51.0 \pm 0.4 \mathrm{~A}$ & $83.3 \pm 0.4 \mathrm{~A}$ \\
\hline $\mathrm{P} 1$ & $77.5 \pm 3.4 \mathrm{AB}$ & $354.4 \pm 3.6 \mathrm{~B}$ & $328.8 \pm 4.3 \mathrm{~B}$ & $7.77 \pm 0.3 \mathrm{~B}$ & $50.0 \pm 0.5 \mathrm{~A}$ & $82.7 \pm 0.3 \mathrm{AB}$ \\
\hline $\mathrm{P} 2$ & $70.0 \pm 0.9 \mathrm{~B}$ & $335.6 \pm 5.1 \mathrm{~B}$ & $308.3 \pm 4.5 \mathrm{BC}$ & $6.14 \pm 0.2 \mathrm{BC}$ & $47.0 \pm 0.3 \mathrm{~B}$ & $81.0 \pm 0.3 \mathrm{BC}$ \\
\hline P3 & $69.7 \pm 0.7 \mathrm{~B}$ & $325.8 \pm 4.9 \mathrm{~B}$ & $318.7 \pm 3.1 \mathrm{BC}$ & $5.00 \pm 0.4 \mathrm{C}$ & $46.0 \pm 0.3 \mathrm{~B}$ & $80.3 \pm 0.2 \mathrm{C}$ \\
\hline
\end{tabular}

$\mathrm{T}=$ unfertilized soil. $\mathrm{C} 1=$ mineral fertilization mineral with superphosphate $19-21$ of $\mathrm{P}_{2} \mathrm{O}_{5}$. C2 = mineral fertilization with Top-Phos, Fosfactyl of $\mathrm{P}_{2} \mathrm{O}_{5} . \mathrm{C} 3=$ mineral fertilization with $1 / 2$ Top-Phos, Fosfactyl $+1 / 2$ mineral superphosphate. $\mathrm{P} 1=70 \mathrm{Mg} \mathrm{ha}^{-1}$ wet olive pomace $+60 \mathrm{~kg} / \mathrm{ha} \mathrm{N}$ during stem elongation stage. $\mathrm{P} 2$ and $\mathrm{P} 3=70$ and $0 \mathrm{Mg} \mathrm{ha}^{-1}$ wet olive pomace, respectively, without mineral fertilization. Values $\pm=$ standard errors. Different letters in column indicate significant differences according to the SNK test at $P \leq 0.01$ 
an increase of $66 \%$ in Aureo cv and of $222 \%$ in Vespucci $\mathrm{cv}$, compared to the unfertilized crop. Instead, in treatments P2 and P3 where only organic fertilization was carried out, the yield response of both cultivars did not change with respect to the unfertilized crop (Tables 4 and 5; Fig. 3). Similar results were found in maize from Chatterjee et al. (2018), where the best yield performances were obtained with the addition of $10 \mathrm{Mg} \mathrm{ha}^{-1}$ of wheat residue mulch and $75 \mathrm{~kg} \mathrm{ha}^{-1}$ of mineral N.

Higher yield increases were achieved with mineral fertilization (C1, C2, and C3), with average increases of 301\% and $414 \%$ for the Aureo and Vespucci cultivars, respectively, in comparison to the unfertilized crop (Tables 4 and 5; Fig. 3).

Where different forms of phosphorus were used, no significant differences were found in any of the morphological, physiological, and production parameters determined, with the exception of the hectoliter weight of the cv of Aureo $\left(82 \mathrm{~kg} \mathrm{HL}^{-1}\right)$ which was significant only when the phosphorus was introduced under form of Top-Phos in the treatment C2 (Table 5).

Finally, it was verified if the different fertilization treatments, besides influencing grain yield, were also able to affect the grain protein content (GPC). The protein content was on average greater in Aureo than in Vespucci (11.34 vs

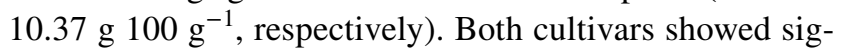
nificantly higher GPC when supplied with the mineral ferti-

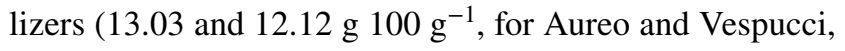
respectively) in comparison to the organic fertilization and the unfertilized crop. In the organic fertilized treatments, the addition of $60 \mathrm{~kg} \mathrm{~N} \mathrm{ha}^{-1}$ (treatment P1) induced a significant increment in GPC $(+18.5 \%)$ in comparison to the fertilization with only wet olive pomace (P2 an P3) (Fig. 4).

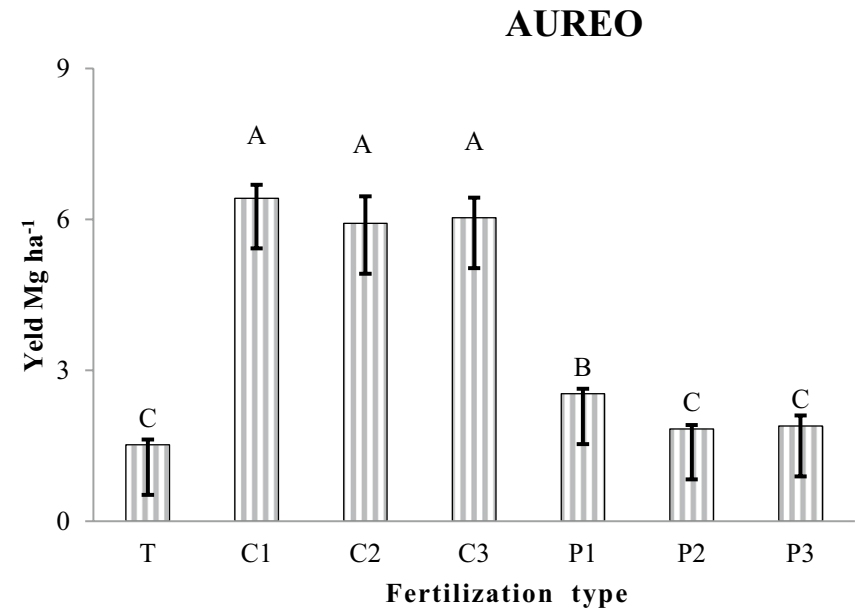

Fig. 3 Grain yield of two durum wheat cultivars supplied with mineral and organic fertilization. $T$ unfertilized soil. $\mathrm{C} 1=$ mineral fertilization mineral with superphosphate $19-21$ of $\mathrm{P}_{2} \mathrm{O}_{5} . \mathrm{C} 2=$ mineral fertilization with Top-Phos, Fosfactyl of $\mathrm{P}_{2} \mathrm{O}_{5}$. C3 $=$ mineral fertilization with $1 / 2$ Top-Phos, Fosfactyl $+1 / 2$ mineral superphosphate.

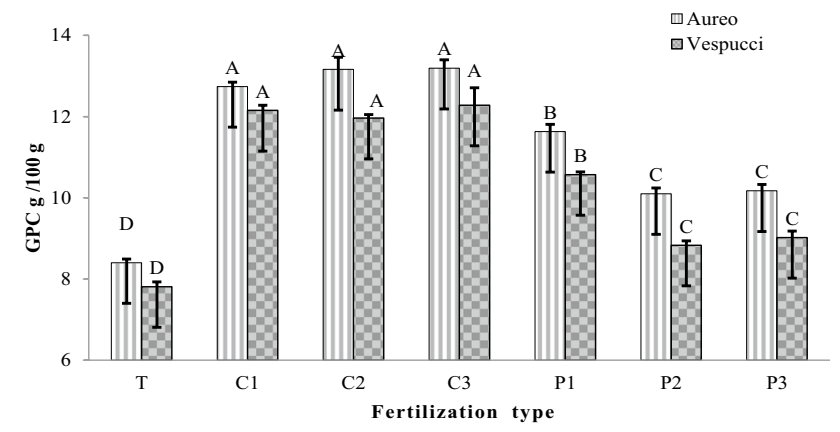

Fig. 4 Grain protein content (GPC) of two durum wheat cultivars supplied with mineral and organic fertilization (values expressed on the basis of standard moisture). $T$ unfertilized soil. $\mathrm{C} 1=$ mineral fertilization mineral with superphosphate $19-21$ of $\mathrm{P}_{2} \mathrm{O}_{5}$. C2 $=$ mineral fertilization with Top-Phos, Fosfactyl of $\mathrm{P}_{2} \mathrm{O}_{5} . \mathrm{C} 3=$ mineral fertilization with $1 / 2$ Top-Phos, Fosfactyl $+1 / 2$ mineral superphosphate. $\mathrm{P} 1=70 \mathrm{Mg} \mathrm{ha}^{-1}$ wet olive pomace $+60 \mathrm{~kg} / \mathrm{ha} \mathrm{N}$ during stem elongation stage. $\mathrm{P} 2$ and $\mathrm{P} 3=70$ and $0 \mathrm{Mg} \mathrm{ha}^{-1}$ wet olive pomace, respectively, without mineral fertilization. Vertical bars represent the standard errors of means. Different letters in column indicate significant differences according to the SNK test at $P \leq 0.01$

Nitrogen fertilization is one of the major strategies used to increase crop yields (Laidig et al. 2017). Furthermore, a good nitrogen fertilization can also increase grain nitrogen content, and, therefore, determine an increase in GPC (Giuliani et al. 2011). In this paper, the effects of both organic and inorganic fertilization on productivity parameters and on GPC in two durum wheat cultivars were studied. Literature data showed that an indirect measurement of the amount of leaf nitrogen and chlorophyll content can be obtained by SPAD values (Cartelat et al. 2005; Debaeke

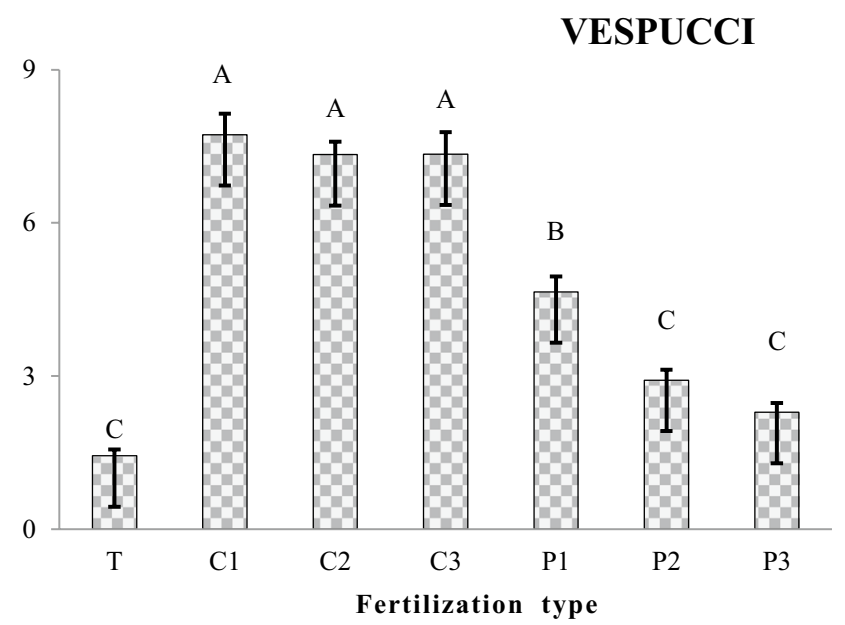

$\mathrm{P} 1=70 \mathrm{Mg} \mathrm{ha}^{-1}$ wet olive pomace $+60 \mathrm{~kg} / \mathrm{ha} \mathrm{N}$ during stem elongation stage. $\mathrm{P} 2$ and $\mathrm{P} 3=70$ and $0 \mathrm{Mg} \mathrm{ha}^{-1}$ wet olive pomace, respectively, without mineral fertilization. Vertical bars represent the standard errors of means. Different letters in column indicate significant differences according to the SNK test at $P \leq 0.01$ 
et al. 2006; Xiong et al. 2015). Our results showed that mineral fertilization increased the SPAD values in both cultivars, at booting and flowering stages, suggesting that inorganic fertilization provides immediately available nitrogen in the soil, which can then be easily absorbed and assimilated by plants. On the contrary, plants fertilized with wet olive pomace showed values lower than those observed with inorganic fertilization, but, at flowering stage, greater than the unfertilized control.

This result confirms that nitrogen present in organic fertilizers is only available to plants in late growth stages (Sørensen and Amato 2002; Guster et al. 2005). The increased availability of nitrogen for plants due to mineral fertilization was also evident from improved agronomic performance, with better results for height, number of culms, number of ears, and shoot dry biomass, which increased significantly in both cultivars.

Literature shows that the shoot biomass increment is closely related to nitrogen availability, and that its increase corresponds to a wider photosynthetic surface and a higher capacity to produce reserve compounds, with a consequent increase in yield (Spano et al. 2003; Masclaux-Daubresse et al. 2008).

These data suggested that, in productive terms, Vespucci responded better to fertilization treatments than Aureo due to its genotype characteristics. The yield of $4.65 \mathrm{Mg} \mathrm{ha}^{-1}$, allowed by a greater thousand seed weight and hectoliter kernel weight, obtained by Vespucci with WP and N $60 \mathrm{~kg} \mathrm{ha}^{-1}$ fertilization (P1 treatment) can be considered satisfactory also from an economic point of view considering the high cost of mineral fertilizers with respect to the reduced transport and spreading costs of WP in the field. The physiological and morphological parameters showed a similar behavior in the two cultivars; therefore, it was not observed a different effect of WP apart from an overall greater productivity in Vespucci.

It has long been known that there is a negative correlation between productivity and GPC, strictly dependent on the genotype (Blanco et al. 2002; Oury and Godin 2007). According to this, our data showed that inorganic fertilization determines an increase in GPC only in the Aureo $\mathrm{cv}$, where the increase in grain production was significantly lower than in Vespucci. The GPC in cv Aureo also significantly increased with the pomace treatment, but no yield increment was observed.

The increase in GPC observed in cv Aureo, treated with both types of fertilizers, can be explained by the process of grain filling occurring in the final stages of plant growth, i.e., during ripening. The amount of nitrogen present in the kernels can depend both on re-mobilization during grain filling of the nitrogen absorbed before flowering (Triboï and Triboi-Blondel 2002), a process strictly dependent on the availability of inorganic nitrogen in the soil (Kichey et al.
2006), and on the capacity of the plants to absorb nitrogen from the soil nitrate during maturation (Bertin and Gallais 2000; Gallais and Coque 2005), a stage in which the nitrogen of the pomace probably becomes available for absorption by the plants.

Indeed, our data showed that cvs Aureo and Vespucci, although starting from comparable values of productivity and GPC, used the nitrogen supplied differently. In fact, Vespucci showed an increase in productivity parameters, while Aureo increased its GPC. So far, while organic fertilization could be useful to improve GPC in specific cultivars, it could be less efficient in improving yield.

The different types of phosphorous supplied had no effect on the two durum wheat cvs growth and yield, as observed also by Molin et al. (2015) who did not find significant effects of the different types of phosphate fertilizers on wheat, probably due to the scarcity of effectiveness of TopFos on calcareous soils.

\section{Conclusions}

From our result, we can assess that wet olive pomace supplied as soil amendment, in the doses based on legislation in force in Italy, for 2 consecutive years, has not been sufficient to significantly improve the yield response of wheat compared to the unfertilized control.

When $60 \mathrm{~kg} \mathrm{ha}^{-1}$ of nitrogen was added before the stage of the stem elongation, in addition to $70 \mathrm{Mg} \mathrm{ha}^{-1}$ of wet olive pomace yield an increase of $66 \%$ in Aureo cv and of $222 \%$ in Vespucci cv, compared to the unfertilized control. These results can be explained with the availability of nutritive elements for the plants only at a late stage of growth when organic fertilization is supplied.

The durum wheat cultivars compared in this study showed a different response in terms of yield and protein increase, indicating a different use of the nitrogen supplied with fertilization; in particular, Vespucci showed an increase of yield parameters, while Aureo showed an improvement of grain protein content. Physiological and morphological parameters showed instead a similar behavior. The good yield response of Vespucci, obtained with WP integrated by mineral N, can be considered satisfactory also from an economic point of view considering the low transport and spreading costs of WP in the field in comparison to the mineral fertilizers costs.

Although the organic is less efficient than the inorganic fertilization in improving wheat productivity, it could be useful to increase crop grain protein content.

The use of wet olive pomace represents an optimal and promising strategy to recycle organic wastes and increase soil organic carbon content, being in line with sustainable agricultural practices. However, its optimal management requires the incorporation in the soil before sowing, to avoid 
phytotoxic effects, as well as the integration with mineral fertilization, particularly for nitrogen supply.

\section{Compliance with ethical standards}

Conflict of interest No potential conflict of interest was reported by the authors.

Open Access This article is distributed under the terms of the Creative Commons Attribution 4.0 International License (http://creativeco mmons.org/licenses/by/4.0/), which permits unrestricted use, distribution, and reproduction in any medium, provided you give appropriate credit to the original author(s) and the source, provide a link to the Creative Commons license, and indicate if changes were made.

\section{References}

Alfano G, Belli C, Lustrato G, Ranalli G (2008) Pile composting of two-phase centrifuged olive husk residues: technical solutions and quality of cured compost. Bioresour Technol 99:4694-4701. https ://doi.org/10.1016/j.biortech.2007.09.080

Andrews M, Edwards GR, Ridgway HJ, Cameron KC, Di HJ, Raven JA (2011) Positive plant microbial interactions in perennial ryegrass dairy pasture systems. Ann Appl Biol 159:79-92. https://doi.org /10.1111/j.1744-7348.2011.00473.x

ANPA (2001) Metodi di analisi del compost: Manuale e Linee Guida. Agenzia Nazionale per la Protezione dell'Ambiente, Rome (in Italian)

AOAC (1990) In: W Horwitz (eds) Official methods of analysis of the association of official analytical chemists, Chap. 4, 15th edn, Method 989.05. Association of Official Analytical Chemists, Arlington

Bertin P, Gallais A (2000) Genetic variation for nitrogen use efficiency in a set of recombinant inbred lines. I. Agrophysiological results. Maydica 45:53-66. https://prodinra.inra.fr/record/57300. Accessed 7 Jan 2019

Blanco A, Pasqualone A, Troccoli A, Di Fonzo N, Simeone R (2002) Detection of grain protein content QTLs across environments in tetraploid wheats. Plant Mol Biol 48:615-623. https://doi. org/10.1023/A:1014864230933

Briccoli C, Godino G, Nuzzo V (2002) Preliminary agronomic evaluation of two cultivars of olive trees obtained from micropropagation methods. Acta Hortic 586:870-876. https://doi.org/10.17660 /ActaHortic.2002.586.188

Butler J, Garratt MPD, Leather SR (2012) Fertilisers and insect herbivores: a meta-analysis. Ann Appl Biol 161:223-233. https://doi. org/10.1111/j.1744-7348.2012.00567.x

Cartelat A, Cerovic ZG, Goulas Y, Meyer S, Lelarge C, Prioul JL, Moya I (2005) Optically assessed contents of leaf polyphenolics and chlorophyll as indicators of nitrogen deficiency in wheat (Triticum aestivum L.). Field Crops Res 91(1):35-49. https://doi. org/10.1016/j.fcr.2004.05.002

Chatterjee S, Bandyopadhyay KK, Pradhanc S, Singhb R, Datta SP (2018) Effects of irrigation, crop residue mulch and nitrogen management in maize (Zea mays L.) on soil carbon pools in a sandy loam soil of Indo-gangetic plain region. Catena 165:207-216. https://doi.org/10.1016/j.catena.2018.02.005

Cucci G, Lacolla G, Caranfa L (2008) Improvement of soil properties by application of olive oil waste. Agron Sustain Dev 28:521e526. https://doi.org/10.1051/agro:2008027
Cucci G, Lacolla G, Caranfa G (2013) Use of composted olive waste as soil conditioner and its effects on the soil. Int J Agr Res 8(4):149_ 157. https://doi.org/10.3923/ijor.2013149.157

Cucci G, Lacolla G, Summo C, Pasqualone A (2019) Effect of organic and mineral fertilization on faba bean (Vicia faba L.). Sci Hortic 3(243):338-343. https://doi.org/10.1016/j.scienta.2018.08.051

Davies G, Lennartsson M (2005) Organic vegetable production. A complete guide. A complete guide. Henry Doubleday Research Association, London

Debaeke P, Rouet P, Justes E (2006) Relationship between the normalized SPAD index and the nitrogen nutrition index: application to durum wheat. J Plant Nutr 29:75-92. https://doi. org/10.1080/01904160500416471

Epstein E, Bloom AJ (2005) Inorganic components of plants. Mineral nutrition of plants: principles and perspectives, 2 nd edn. Sinauer Associates Inc., Massachusetts, pp 44-45

Erana FG, Tenkegna TA, Asfaw SL (2019) Effect of agro industrial wastes compost on soil health and onion yields improvements: study at field condition. Int J Recycl Org Waste Agric 8:1-11. https://doi.org/10.1007/s40093-019-0286-2

Gallais A, Coque M (2005) Genetic variation and selection for nitrogen use efficiency in maize, a synthesis. Maydica 50:531-547

Giuliani MM, Giuzio L, De Caro A, Flagella Z (2011) Relationships between nitrogen utilization and grain technological quality in durum wheat: II. Grain yield and quality. Agron J 103(6):16681675. https://doi.org/10.2134/agronj2011.0154

Guster R, Ebertseder T, Weber A, Schraml M, Schmidhalter U (2005) Short-term and residual availability of nitrogen after long-term application of organic fertilizer on arable land. J Plant Nutr Soil Sci 168:439-446. https://doi.org/10.1002/jpln.200520510

Italian law No. 574 of 11 th November 1996. Nuove norme in materia di utilizzazione agronomica delle acque di vegetazione e di scarichi dei frantoi oleari. Published on Italian official gazette No. 265 of 12th November 1996 (in Italian)

Kichey T, Heumez E, Pocholle D, Pageau K, Vanacker H, Dubois F, Hirel B (2006) Combined agronomic and physiological aspects of nitrogen management in wheat highlight a central role for glutamine synthetase. New Phytol 169(2):265-278. https://doi. org/10.1111/j.1469-8137.2005.01606.x

Krapp A (2015) Plant nitrogen assimilation and its regulation: a complex puzzle with missing pieces. Curr Opin Plant Biol 25:115-122. https://doi.org/10.1016/j.pbi.2015.05.010

Laidig F, Piepho HP, Rentel D, Drobek T, Meyer U, Huesken A (2017) Breeding progress, environmental variation and correlation of winter wheat yield and quality traits in German official variety trials and on-farm during 1983-2014. Theor Appl Genet 130(1):223-245. https://doi.org/10.1007/s00122-016-2810-3

Lin C, Chen X, Jian L, Shi C, Jin X, Zhang G (2014) Determination of grain protein content by near-infrared spectrometry and multivariate calibration in barley. Food Chem 162:10-15. https ://doi.org/10.1016/j.foodchem.2014.04.056

Marschner H (1995) Mineral nutrition of higher plants. Academic Press, London, p 889. https://doi.org/10.1006/anbo.1996.0155

Masclaux-Daubresse C, Reisdorf-Cren M, Orsel M (2008) Leaf nitrogen remobilisation for plant development and grain filling. Plant Biol 10(Suppl. 1):23-36. https://doi.org/10.111 1/j.1438-8677.2008.00097.x

Molin PVD, Rampim L, Fávero F, do Lana MC, Sarto MVM, Rosset JS, Mattei D, Diel PS, Molin RND (2015) Response to simple superphosphate and top-phos fertilizer on wheat in an Oxisoil. Tropical Subtrop Agroecosyst 18:121-132

Montemurro F, Convertini G, Ferri D (2004) Mill wastewater and olive pomace compost as amendments for rye-grass. Agronomie 24:481-486. https://doi.org/10.1051/agro:2004044

Oury FX, Godin C (2007) Yield and grain protein concentration in bread wheat: how to use the negative relationship between 
the two characters to identify favourable genotypes? Euphytica 157(1-2):45-57. https://doi.org/10.1007/s10681-007-9395-5

Paris P (1998) Aspetti agronomici dell'impiego dei reflui dell'industria agro-alimentare. Riv Agron 32:196-220

Quaranta F, Belocchi A, Cecchini C, Mazzon V, Fornara M (2016) Le varietà di grano duro per le semine 2016. L'informatore Agrario 33(Suppl. 1):1-37

Saviozzi A, Levi-Minzi R, Riffaldi R, Lupetti A (1991) Effetti dello spandimento di acque di vegetazione su terreno agrario. Agrochimica 35:135-148

Singleton VL, Orthofer R, Lamuela-Raventos RM (1999) Analysis of total phenols and other oxidation substrates and antioxidants by means of Folin-Ciocalteu reagent. Methods Enzymol 299:152178. https://doi.org/10.1016/S0076-6879(99)99017-1

Sørensen P, Amato M (2002) Remineralization and residual effects of $\mathrm{N}$ after application of pig slurry to soil. Eur J Agric 16:81-95. https://doi.org/10.1016/S1161-0301(01)00119-8
Spano G, Di Fonzo N, Perrota C, Platani C, Ronga G, Lawlor QW, Napier JA, Shewry PR (2003) Physiological characterization of 'stay green' mutants in durum wheat. J Exp Bot 54:1415-1420

Triboï E, Triboi-Blondel AM (2002) Productivity and grain or seed composition: a new approach to an old problem. Eur J Agron 16:163-186. https://doi.org/10.1016/S1161-0301(01)00146-0

Xiong D, Chen J, Yu T, Gao W, Ling X, Li Y, Huang J (2015) SPADbased leaf nitrogen estimation is impacted by environmental factors and crop leaf characteristics. Sci Rep 5:13389. https://doi. org/10.1038/srep13389

Zhang J, Kirkham MB (1996) Antioxidant responses to drought in sunflower and sorghum seedlings. New Phytol 132(3):361-373. https://doi.org/10.1111/j.1469-8137.1996.tb01856.x

Publisher's Note Springer Nature remains neutral with regard to jurisdictional claims in published maps and institutional affiliations. 